\title{
Rural Institutions and Planned Change in Agriculture: A Comparative Perspective in Two Punjabs
}

\author{
KHALid Mustafa, ZulfiQAR AHMAD GILL, and RAshid NAEEM
}

\section{INTRODUCTION}

Agricultural change in the Indian and Pakistan Punjabs has been brought about by their respective governments through formal organisations-cooperatives, credit banks, agriculture departments and/or special interest groups at the local level. The changes produced during 1960s and in subsequent period were dramatic but unsettling. Many have argued that the achievement of agricultural change in the region has depended to an important extent on the effectiveness of rural institutions in executing their role as agents of planned change. ${ }^{1}$

The present paper seeks to review the debate on the role of rural institutions in producing social and economic changes in the agrarian sectors of the Indian and Pakistan Punjabs and present some of the data which have stimulated this debate. The paper commences with an overview of the agrarian change in the two Punjabs. Then the programmes of planned change in the two regions are described, and the particular institution of change-cooperatives, credit banks, agricultural departments etc. are discussed in detail. At the specific level, the study aims at delineating the role played by rural institutions in initiating, stimulating, sustaining or retarding change in agriculture sectors of the two Punjabs. The role of rural institutions as a policy instrument for the promotion of agricultural expansion is examined. And finally the paper points out the implications of the past experience for the future role of rural institutions in the two Punjabs.

Khalid Mustafa and Zulfiqar Ahmad Gill are associated with the Faculty of Agricultural Economics and Rural Sociology, University of Agriculture, Faisalabad, and Rashid Naeem is associated with the Department of Economics, Allama Iqbal Open University, Islamabad.

${ }^{1}$ See Sims (1988) Political Regimes, Public Policy and Economic Development: Agricultural Performance and Rural Change in the Two Punjabs; For a review on the effectiveness of rural institutions as agents of change see Halpern (1967) The Changing Village Community; Foster (1962) Traditional Culture and Impact of Technical Change; Myrdal (1968) Asian Drama. 


\section{"PLANNED CHANGE": CONCEPTUAL FRAMEWORK}

"Planned change" implies a purposeful decision to effect improvements, usually with the help of professional guidance. Such change may be introduced by central agencies through formal organisations or special interest groups established at the local level. The achievement of development depends to an important extent on the effectiveness of the local institutions in executing their role as agent of planned change. $^{2}$

Most countries have embarked on programmes of planned change with a public commitment to plan from below and encourage popular participation in plan formulation and implementation. This would require, in addition to an effective national administrative machinery, some kind of institutional structure at the village level, which most less developed countries (LDC's) ${ }^{3}$ do not possess. Thus the development of an infrastructure at the village level is of considerable importance if ambitious development plans involving popular participation are to become even a partial reality.

Nevertheless the problem is how to build rural institutions and resolve the issues involved such as the new and old institutions, tussle-should the traditional institutions be discarded altogether as incapable and incompatible with the present needs; or the question of giving autonomy to rural institutions from external control that may eventually turn them into parasitic bodies/institutions or devices of totalitarian control. It is a question of timing. If external control is with-drawn at a stage when the environment is hostile, the new institutions may find it difficult to take root. Or if they continue to exist, they may cease to perform the original function of bringing about change, and, instead become prisoners of the traditional forces.

In seeking an answer to the issues raised three main subjects of interest receive particular attention (a) the process of development of rural institutions and their role in the introduction of planned change in agriculture (b) the role of the peasantry (and/or special interest groups) itself as a system conditioning the development of the institutions and its level of performance (c) the role of the government and other external linkages as they might affect the course of development of institutions in the rural settings. The performance of rural institutions in the two Punjabs is viewed in the context of these various considerations.

\section{THE GENERAL SETTING IN TWO PUNJABS}

The Indian and Pakistan's Punjabs, provide an interesting case study in comparative agrarian performance and development. Both regions have historically been the most developed and continue to be so today. In Pakistan the Punjab

${ }^{2}$ See Myrdal (1968) Asian Drama.

${ }^{3}$ This is a controversy pervading the literature on local institutions for Myrdal's Judgment that existing local structure "is weak and “inimical to development”, see Asian Drama (1968), p. 859. 
province comprising around 26 percent of the total area and a population of 47.3 million representing 56 percent of the total population, appears to 'dominate' the political and economic scene. In contrast, the Indian Punjab, comprising only 1.57 per cent of area and a population of 20.28 million, representing a mere 2.5 percent of the total population, contributes significant share from its agricultural output to the central pool (during 1996-97 the percentage share to the central pool in wheat and rice was 69 per cent and 57 per cent respectively). ${ }^{4}$

The two Punjabs have pretty much the same climate, both started off with similar agro-economical and land tenure systems and both share a common culture, language, historical traditions and institutional arrangements. Furthermore, both regions have since the mid-1960s experienced rapid technological change associated with the so called 'green revolution' technology. Yet, in terms of agricultural development, the Indian Punjab has shown relatively better performance. ${ }^{5}$ (See Table 1 ).

The superior agricultural performance of Indian Punjab, as demonstrated by almost twice the rate of productivity, owes its origins to the well-established facilities in social infrastructure, higher irrigation intensity of private tubewells, a greater use of fertilisers and insecticides and a more stable price policy in agriculture in India than in Pakistan. These policies may also be traced back to the nature of the political regimes and the consequent role of political leadership in the two countries. ${ }^{6}$

In addition, the agrarian structure of the Indian Punjab, it is argued, proved to be more conducive to the development of agriculture than was the case for Pakistan Punjab. Whereas in the Pakistan Punjab big landlords, dominate the rural scene, the case in the Indian Punjab is that majority of the area is under owner-cultivation, predominantly in the hands of the middle and rich peasantry. Owner-cultivation and smaller size of holdings, helped by effective land consolidation and land reform policies, have proved to be a vital factor in the Indian Punjab's success in agricultural development. ${ }^{7}$ (See Table 2).

${ }^{4}$ See Aulakh et al. (1998) 'Vision' 2020-Perspective Plan'. p. 47; Singh (1999) Punjab Agricultural Hand Book, pp. 7-8.

${ }^{5}$ See Ahmad and Chaudhry (1996) Productivity Differentials between Pakistan and Indian Punjabs: An Analysis.

${ }^{6}$ See Sims (1988) Political Regimes, Public Policy and Economic Development: Agricultural Performance and Rural Change in the two Punjabs, Day and Sing (1977) Economic Development as an Adoptive Process: The Green Revolution in Indian Punjab.

${ }^{7}$ See for instance Randhawa (1954) out of Ashes, An Account of the Rehabilitation of Refugees from West Pakistan to the Rural Areas of East Punjab; Aulakh (1998); Sims (1988); For an informative discussion of the success of the earlier phase of land consolidation in the Indian Punjab and its impact on investment in Tubewells and agricultural productivity see Kudaisya (1995) The Demographic Upheaval of Partition: Refugees and Agricultural Settlement in India, 1947-67 in South Asia, 18, Special Issue (1995), pp. 73-94; Also see Randhawa (1974) Green Revolution: A Case Study of Punjab. 
Table 1

Selected Statistics About Comparative Performance of Agriculture in Two Punjabs

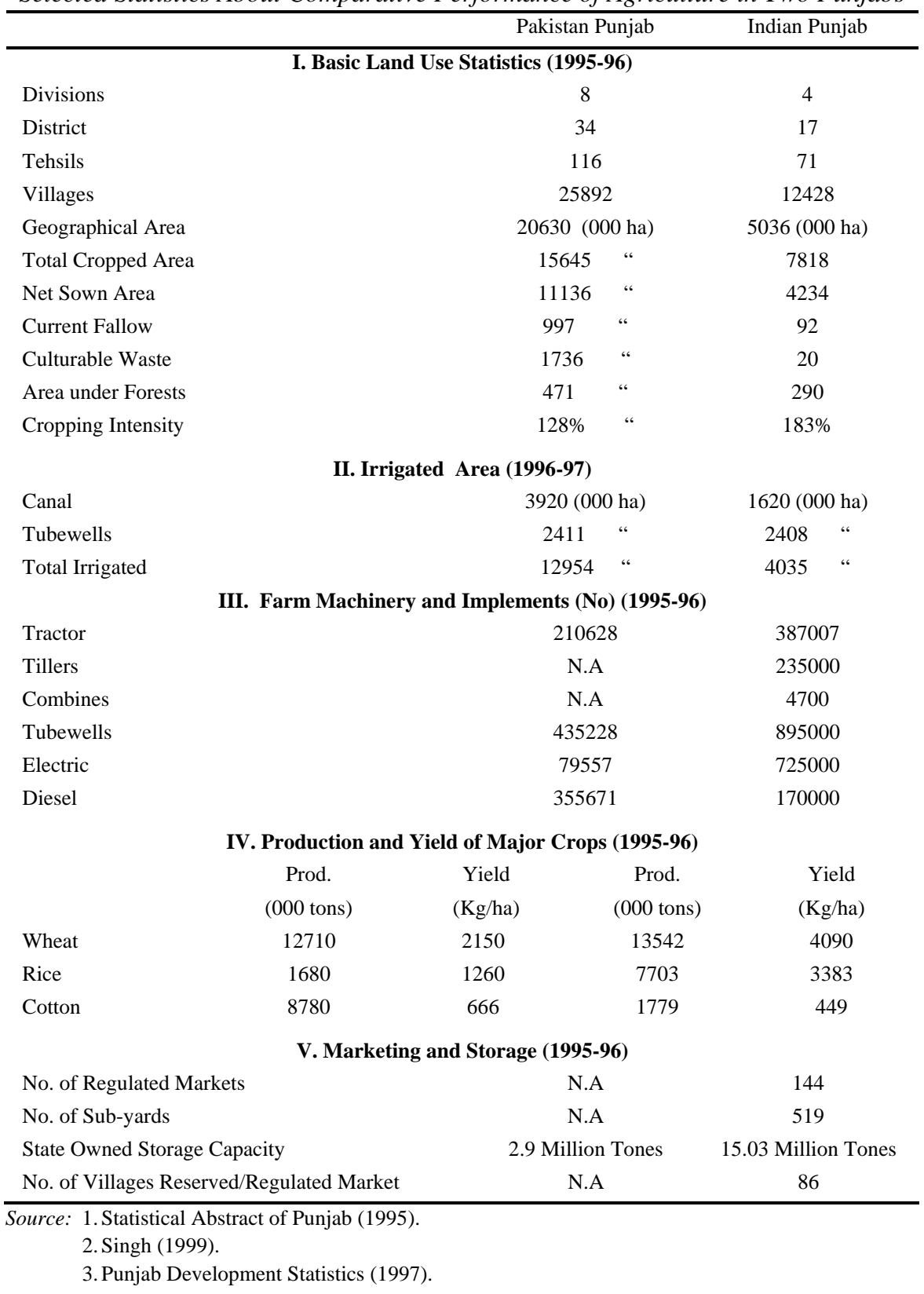


Table 2

Distribution of Land Holdings in Two Punjabs (1990-91)

\begin{tabular}{|c|c|c|c|}
\hline \multicolumn{2}{|c|}{$\begin{array}{c}\text { Indian Punjab } \\
\text { No. of Operational Holding }\end{array}$} & \multicolumn{2}{|c|}{$\begin{array}{c}\text { Pakistan Punjab } \\
\text { Distribution of Land Ownership }\end{array}$} \\
\hline Size of Holdings & $\begin{array}{l}\text { Number } \\
\text { (Percent) }\end{array}$ & $\begin{array}{l}\text { Owners } \\
\text { (Percent) }\end{array}$ & $\begin{array}{c}\text { Area } \\
\text { (Percent) }\end{array}$ \\
\hline \multirow[t]{2}{*}{ Upto 2 Hect. } & 44.74 & 53.48 & 14.07 \\
\hline & 79.2 & 83.75 & 41.94 \\
\hline 2-5 Hect. & 34.46 & 29.87 & 27.87 \\
\hline 5-10 Hect. & 14.78 & 10.79 & 21.17 \\
\hline 10-20 Hect. & 5.00 & 4.06 & 15.40 \\
\hline 20 \& Above & 1.01 & 1.78 & 21.46 \\
\hline
\end{tabular}

Calculated from data contained in the

Source: 1. Statistical Abstract of Punjab (1995).

2. Punjab Development Statistics (1997).

The major effect of the differences in agrarian structure (as also reflected in the differences in political power structures) have important implications for the manner and intensity of utilisation of new technology as and when it became available. In the Pakistan Punjab a small minority of large landowners controlling a majority of the land and monopolising the agricultural inputs market are believed to have largely appropriated the benefits, channeled through rural institutions whereas in the Indian Punjab, it was both the middle and the rich peasants, managing most of the land, who seized the opportunities for capitalist agriculture. Thus in the former case benefits remained restricted to a small minority whereas in the latter benefits were diffused throughout the peasantry, albeit disproportionately. ${ }^{8}$

The performance, achievements and set-backs of rural institutions in initiating agricultural change in the two Punjabs are now dealt in the next section.

\section{RURAL INSTITUTIONS AND PLANNED CHANGE IN TWO PUNJABS}

\section{Cooperatives as Agents of Change}

Cooperatives in the Indo-Pakistan sub-continent were introduced by the British colonial regime at the turn of 19th Century. The succeeding independent governments in India and Pakistan in general followed the patterns of sponsorship and organisation set by the colonial rulers in undivided India.

${ }^{8}$ There has been a lively debate in the Indian and Pakistan Punjabs as to the differential benefits of the green revolution technology, see for instance Hussain (1982) "Technical Change and Social Polarisation in Rural Punjab” in Ali (ed). 'The Political Economy of Rural Agrarian Structure in Pakistan'; Ahmad and Chaudhry (1996), pp. 40-42; Aulakh (1998), p. 63; Mavi (1992) The Punjabs of India and Pakistan. 
Rural cooperatives were not strongly emphasised as a vehicle for agrarian change in the Indian and Pakistan Punjabs in the years immediately following independence of India and Pakistan, but during the 1960s when agricultural development was given greater emphasis, a certain number of cooperatives were organised to supply fertilisers and improved seed. In Pakistan Punjab, cooperatives served primarily as channels of government funds to funnel credit, and improved farm inputs to increase food production and agricultural productivity. This role assigned to cooperatives made them an extension of government's welfare and expenditure policy rather than making them worthwhile self-sustaining institutions in their own right. ${ }^{9}$

On the other hand, cooperatives in the Indian Punjab received a boost under state patronage. By 1971, all villages in the state were covered by primary agricultural credit societies and membership had risen to 1.5 million farmers which accounted for 98 percent of the farming households in the state. ${ }^{10}$ (See Table 3).

Almost all societies in the Indian Punjab were found active undertakings and 75 percent members borrowed from these societies. The supply of rural credit in the Indian Punjab was augmented through land development Banks (LDBS). These banks catered to medium and long term credit needs in the state. In 1970-71, 51 percent of the loans advanced by LDBS were provided for installation of tubewells. ${ }^{11}$

Although the overall record of expansion of rural credit through the institution of cooperatives in the Indian Punjab has been impressive in recent years, it conceals large variations among different farm size groups. Many studies undertaken in the Indian Punjab reveal that large farmers and the politically strong groups dominated the societies and utilised the services for their own purpose. ${ }^{12}$ The National Council of Applied Economic Research in its Survey of 3000 Indian farmers established that cooperative credit was indiscriminately granted to the privileged class. It was established that cooperative credit went largely to better-off farmers. Fortysix percent of cooperatives' credit was disbursed to large farmers (defined here as those owning more than 4 hectares of land) who formed only 29 percent of the cooperatives' borrowing clients, while 54 percent was disbursed among the remaining 71 percent of their clients (small farmers). ${ }^{13}$

\footnotetext{
${ }^{9}$ See Mustafa (1992) The Institution of Cooperation, Credit and the Process of Development in the Indian and Pakistan Punjabs', unpublished Ph. D. Thesis; Also see Chaudhry and Rizwani (1970) Role of Cooperative Institutions in Planned Change.

${ }^{10}$ See Chaudhry and Dasgupta (1985) Agriculture and the Development Process-A Study of Punjab, p. 56; Govt. of Punjab (1985) Facts about Punjab, pp. 75-86.

${ }^{11}$ See Singh and Roupra (1982) Achievements of Punjab Cooperatives at a Glance, pp. 18-21.

${ }^{12}$ See Myrdal (1968), p. 1338; also see Sims (1988).

${ }^{13}$ India (1974) National Council for Applied Economics Research, Credit Requirements for Agriculture, p. 100
} 
Table 3

Growth of Cooperatives at a Glance in Two Punjabs

\begin{tabular}{|c|c|c|c|c|c|c|c|c|c|c|c|c|c|c|c|c|c|c|}
\hline \multirow[b]{3}{*}{ Years } & \multicolumn{5}{|c|}{ No. of Cooperatives } & & \multicolumn{5}{|c|}{ Membership (No: Million) } & & \multicolumn{6}{|c|}{ Working Capital (Rs Million) } \\
\hline & \multicolumn{3}{|c|}{ WP } & \multicolumn{3}{|c|}{ EP } & \multicolumn{3}{|c|}{ WP } & \multicolumn{3}{|c|}{ EP } & \multicolumn{3}{|c|}{ WP } & \multicolumn{3}{|c|}{ EP } \\
\hline & Total & PACS & $\begin{array}{c}\text { All } \\
\text { Others }\end{array}$ & Total & PACS & $\begin{array}{c}\text { All } \\
\text { Other }\end{array}$ & Total & PACS & $\begin{array}{c}\text { All } \\
\text { Others }\end{array}$ & Total & PACS & $\begin{array}{c}\text { All } \\
\text { Others }\end{array}$ & Total & PACS & $\begin{array}{c}\text { All } \\
\text { Others }\end{array}$ & Total & PACS & $\begin{array}{c}\text { All } \\
\text { Others }\end{array}$ \\
\hline 1980-81 & 41533 & 23515 & 18018 & 21992 & 4271 & 17721 & 1.65 & 0.88 & 0.76 & 2.98 & 1.75 & 1.23 & 2433 & 666 & 1766 & 11765 & 1811 & 9954 \\
\hline 1985-86 & 48557 & 30596 & 17961 & 24785 & 4235 & 20550 & 2.21 & 1.27 & 0.94 & 3.46 & 1.89 & 1.57 & 4389 & 895 & 3494 & 24606 & 4024 & 20582 \\
\hline 1990-91 & 46197 & 33302 & 12895 & 27003 & 4633 & 22370 & 2.40 & 1.46 & 0.94 & 3.96 & 2.04 & 1.92 & 14393 & 1840 & 12552 & 44946 & 7166 & 37780 \\
\hline 1994-95 & 47244 & 34669 & 12575 & 22675 & 4205 & 18470 & 2.46 & 1.61 & 0.85 & 4.19 & 2.06 & 2.13 & 10719 & 2722 & 799 & 75854 & 9459 & 66395 \\
\hline
\end{tabular}

Source: 1. Statistical Abstract of Punjab (1995).

2. Annual reports of working of cooperatives in Punjab (Various Issues).

3. Facts about Punjab-1987 (1988).

EP: Indian Punjab.

WP: Pakistan Punjab. 
As could be expected, large farmers benefitted much more than the small farmers. ${ }^{14}$ From the availability of cheap credit, in the Indian Punjab with average nominal rates of interest of about 9-10 percent in a situation where the inflation rate was about 10 percent.

On the other hand, out of a total 60562 cooperatives established in Pakistan in 1992, some 93 percent were founded in Punjab. These societies owned 92 percent of the working capital and 95 percent of total membership of all cooperatives established in the country. Despite their steady growth some 60-95 percent cooperatives in Punjab were regarded bogus, fictitious and/or one-man undertakings. ${ }^{15}$ It is reported that most societies in Pakistan Punjab were established by the influential, who enrolled their relatives and farm workers as members of the cooperatives in order to avail the facilities (usually subsidised credit) offered by the societies. It has been alleged that influential members have often absconded with the money advanced by these societies. ${ }^{16}$ (See Table 4 for relevant data on the working of credit cooperatives in two Punjabs).

\section{Rural Credit and Marketing Institutions}

The importance of institutional sources of rural credit in the two Punjabs may be judged from the data presented in Table 5. It may be seen that the supply of institutional credit in the Indian and Pakistan Punjabs enhanced considerably between 1960s through 1990s. A major share of the supply of institutional credit in the two Punjabs came from agricultural credit societies. Nevertheless, supply of rural credit after mid 1970s was augmented through other sources-land Development Banks and commercial Banks in the Indian Punjab and Agricultural Development Bank and Commercial Banks in the Pakistan Punjab.

A study carried out in the IADP district of the Ludhiana district (Indian Punjab) established that cooperatives met 63 percent of the total volume of credit borrowed by the sample farmers. The nationalised banks provided another 18 percent; thus 81 percent of total credit was provided by institutional agencies. Money-lenders, friends and relatives provided the remaining 19 percent. ${ }^{17}$ Chaudhri and Dasgupta ${ }^{18}$ found that for the Indian Punjab as a whole, farmers in the largest size group obtained on an average nearly 90 percent of their credit from the government and cooperative agencies whereas farmers in the smallest size group obtained about 70 percent of their credit from these sources. The traditional source,

${ }^{14}$ See Chaudhry and Dasgupta (1985), pp. 56-57.

${ }^{15}$ See Pakistan (1988) Report of the National Commission on Agriculture, p. 401; also see Centre for Administrative Research and Development (1984) Agricultural Cooperative Movement in Pakistan.

${ }^{16}$ See Mustafa (1992), Chapter 7.

${ }^{17}$ See Singh (1972), pp. 27-33.

${ }^{18}$ Chaudhry and Dasgupta (1985), pp. 99-102. 
Table 4

Selected Statistics of Agricultural Credit Cooperatives in Two Punjabs

\begin{tabular}{|c|c|c|c|c|c|c|c|c|c|c|c|c|c|}
\hline & & \multicolumn{2}{|c|}{ No. of Cooperatives } & \multicolumn{2}{|c|}{ Membership } & \multicolumn{2}{|c|}{ Working Capital } & \multicolumn{2}{|c|}{ Loans Advanced } & \multicolumn{2}{|c|}{ Loans Recovered } & \multicolumn{2}{|c|}{$\begin{array}{c}\text { Ratio of Repayment to Loans } \\
\text { Advanced }\end{array}$} \\
\hline & & $\overline{\mathrm{PACS}}(\mathrm{No})$ & PACS (No) & $\begin{array}{l}\text { Members (No. } \\
\text { Million) }\end{array}$ & $\begin{array}{l}\text { Members (No. } \\
\text { Million) }\end{array}$ & $\begin{array}{c}\text { Working } \\
\text { Capital (Rs) }\end{array}$ & $\begin{array}{c}\text { Working } \\
\text { Capital (Rs) }\end{array}$ & $\begin{array}{l}\text { Loand } \\
\text { Advanced } \\
\text { (Rs) }\end{array}$ & $\begin{array}{c}\text { Loans } \\
\text { Advanced } \\
\text { (Rs) }\end{array}$ & $\begin{array}{c}\text { Loans } \\
\text { Recovered } \\
\text { (Rs) }\end{array}$ & $\begin{array}{c}\begin{array}{c}\text { Loans } \\
\text { Recovered } \\
\text { (Rs) }\end{array} \\
\end{array}$ & $\begin{array}{c}\text { Ratio of } \\
\text { Repayment to } \\
\text { Loan Advanced }\end{array}$ & $\begin{array}{c}\text { Ratio of } \\
\text { Repayment to } \\
\text { Loan } \\
\text { Advanced }\end{array}$ \\
\hline \multicolumn{2}{|l|}{ Year } & WP & EP & WP & EP & WP & EP & WP & EP & WP & EP & WP & EP \\
\hline \multicolumn{2}{|l|}{$1960-61$} & 10822 & 18448 & 0.39 & 1.29 & 46.51 & 210.86 & 32.07 & 117.60 & 25.63 & $\mathrm{NA}$ & 0.79 & $\mathrm{NA}$ \\
\hline \multirow{2}{*}{\multicolumn{2}{|c|}{$\begin{array}{l}1965-66 \\
1970-71\end{array}$}} & 12121 & 11064 & 0.51 & 1.28 & 75.09 & 368.30 & 34.18 & 248.86 & 43.08 & 185.79 & 1.26 & 0.74 \\
\hline & & 12652 & 10932 & 0.59 & 1.46 & 98.53 & 765.03 & 41.22 & 572.65 & 12.57 & 563.30 & 0.30 & 0.98 \\
\hline \multicolumn{2}{|l|}{$1975-76$} & 12658 & 10936 & 0.63 & 1.62 & 143.76 & 1094.21 & 79.88 & 749.75 & 28.25 & 749.74 & 0.35 & 1.00 \\
\hline \multicolumn{2}{|l|}{$1980-81$} & 23515 & 4266 & 0.88 & 1.78 & 633.99 & 2312.43 & 979.99 & 1992.06 & 819.00 & 1632.23 & 0.83 & 0.82 \\
\hline \multicolumn{2}{|l|}{$1985-86$} & 30596 & 4235 & 1.27 & 1.89 & 895.43 & 4024.80 & 1055.71 & 3121.90 & 1208.66 & 2934.58 & 1.14 & 0.94 \\
\hline \multirow{2}{*}{\multicolumn{2}{|c|}{$1990-91$}} & 33302 & 4633 & 1.46 & 2.04 & 1840.54 & 7166.35 & 1346.09 & 3463.06 & 1275.82 & 3328.31 & 0.94 & 0.96 \\
\hline \multirow{5}{*}{$\frac{1994-95}{\text { Source: }}$} & & 34669 & 4205 & 1.61 & 2.06 & 2722.70 & 9459.71 & 3302.70 & 8527.32 & 3186.00 & 7926.19 & 0.96 & 0.92 \\
\hline & 1. & ievementso & ab Cooper & at a Glance Th & rough Statistical & Data from 1967 & to 1981 (1983) & & & & & & \\
\hline & 2. & $\begin{array}{l}\text { Statistical Abstrac } \\
\text { Anpual reports of }\end{array}$ & of Punjab (19؟ & & & & & & & & & & \\
\hline & $\begin{array}{l}3 . \\
3 .\end{array}$ & $\begin{array}{l}\text { Annual reports of } \\
\text { Facts about Punjal }\end{array}$ & $\begin{array}{l}\text { vorking of cool } \\
-1987 \text { (1989). }\end{array}$ & s in Punj & (Various issues). & & & & & & & & \\
\hline & EP: 1 & Indian Punjab. V & 政 & & & & & & & & & & \\
\hline
\end{tabular}

Table 5

Institutional Agricultural Credit Supplied in two Punjabs.

\begin{tabular}{|c|c|c|c|c|c|c|c|c|c|c|}
\hline & $\begin{array}{l}\text { PACS } \\
\text { WP }\end{array}$ & $\begin{array}{c}\text { PACS } \\
\text { EP }\end{array}$ & $\begin{array}{l}\text { Agri. Bank } \\
\text { WP }\end{array}$ & $\begin{array}{l}\text { Agri. Bank } \\
\text { EP }\end{array}$ & $\begin{array}{l}\text { Taccavi } \\
\text { WP }\end{array}$ & $\begin{array}{l}\text { Taccavi } \\
\text { EP }\end{array}$ & $\begin{array}{l}\text { Comm. Banks } \\
\text { WP }\end{array}$ & $\begin{array}{c}\text { Comm. Banks } \\
\text { EP }\end{array}$ & $\begin{array}{l}\text { Total } \\
\text { WP }\end{array}$ & $\begin{array}{l}\text { Total } \\
\text { EP }\end{array}$ \\
\hline $1960-61$ & 69.52 & 139.50 & & & 560 & $\mathrm{NA}$ & - & - & 75.12 & 139.50 \\
\hline $1965-66$ & 78.39 & 275.50 & 48.30 & 17.50 & 3.80 & $\begin{array}{l}\text { N.A. } \\
107.30\end{array}$ & - & $\begin{array}{l}- \\
-\end{array}$ & 130.49 & 400.30 \\
\hline $1970-71$ & 99.29 & 572.70 & 77.30 & 180.10 & 3.70 & 43.50 & - & - & 173.27 & 1796.30 \\
\hline 1975-76 & 81.54 & 749.70 & 396.31 & $\begin{array}{l}100.10 \\
145.70\end{array}$ & 12.13 & N.A & 52.90 & 274.70 & $\begin{array}{l}1010.88 \\
1017\end{array}$ & $\begin{array}{l}1170.10 \\
110\end{array}$ \\
\hline $1980-81$ & $\begin{array}{l}01.04 \\
979.99\end{array}$ & 1992.10 & 711.55 & 360.10 & 8.22 & $\begin{array}{l}\text { N.A } \\
\text { N.A }\end{array}$ & 1587.40 & $\begin{array}{l}2351.20 \\
2351 .\end{array}$ & 3015.79 & 4703.40 \\
\hline $\begin{array}{l}1980-81 \\
1985-86\end{array}$ & $\begin{array}{l}919.99 \\
2110.00\end{array}$ & $\begin{array}{l}1999.110 \\
3121.90\end{array}$ & $\begin{array}{l}111.55 \\
2581.00\end{array}$ & $\begin{array}{l}360.10 \\
466.10\end{array}$ & $\begin{array}{l}8.22 \\
4.65\end{array}$ & $\begin{array}{l}\text { N.A } \\
\text { N.A }\end{array}$ & $\begin{array}{l}158.740 \\
2207.00\end{array}$ & $\begin{array}{l}2351.20 \\
5918.20\end{array}$ & $\begin{array}{l}3015 . / 9 \\
6902.65\end{array}$ & $\begin{array}{l}4 / 73.40 \\
9506.20\end{array}$ \\
\hline $1990-91$ & 3034.00 & 3463.06 & 6225.00 & 581.00 & 7.00 & N.A & 1772.00 & 11670.80 & 11038.00 & 15714.86 \\
\hline $\begin{array}{l}1909-91 \\
1994-95\end{array}$ & $\begin{array}{l}\begin{array}{r}0353.40 \\
3302.00\end{array} \\
3\end{array}$ & $\begin{array}{l}3465.06 \\
8527.32\end{array}$ & $\begin{array}{l}6225.00 \\
10015.00\end{array}$ & $\begin{array}{r}5181.00 \\
1519.39\end{array}$ & $\begin{array}{l}.00 \\
13.80\end{array}$ & $\begin{array}{l}\text { N.A } \\
\text { N.A }\end{array}$ & $\begin{array}{l}17 / 2.00 \\
1968.00\end{array}$ & $\begin{array}{l}111 / 0.80 \\
13890.21\end{array}$ & $\begin{array}{l}110288.00 \\
1528.80\end{array}$ & $\begin{array}{l}151 / 4.86 \\
23936.92\end{array}$ \\
\hline
\end{tabular}

Development statistics (Various Issues).

EP: Indian Punjab. WP: Pakistan Punjab. 
namely the village money-lender, was insignificant for the largest farm size group although it still contributed about 20 percent of all borrowing by small farmers. In contrast, credit needs of the farm sector in the Pakistan Punjab remained largely unmet from the institutional sources. The Rural Credit Survey recorded that only 30 percent of small and 44 percent of large farm households in Pakistan had some recourse to institutional credit. The survey established that 34 percent of the under 0.5 hectare category had recourse to institutional credit, as against 65 percent of the total farm households in the Pakistan Punjab. ${ }^{19}$ These findings support that insufficient credit was available form institutional sources and that farmers depended more on non-institutional sources to fulfill their credit needs in the Pakistan Punjab, compared with that in the Indian Punjab.

In the marketing of farm produce and provision of farm requisites, marketing institutions in the two Punjabs have had a mixed and not particularly significant record. The limited number of marketing societies in the two Punjabs established during the decade, 1950-60, did not make significant contribution as most of these societies depended heavily on government patronage. In Pakistan Punjab, marketing societies were used as a vehicle to funnel food grain and consumer goods to the rural population during the periods of post-independence stringency. Later, however, these societies took up their traditional role. Nevertheless, they generally failed in undertaking the assigned task. And this was in part due to the absence of viable apex and secondary level cooperative marketing structures. ${ }^{20}$ In recent years, some progress has been shown by the Punjab Agricultural Cooperatives Supply and Marketing Federation in Pakistan Punjab. The federation deals in procuring chemical fertilisers, seeds, pesticides and farm machinery from the private sector and ensures their delivery at the farmer's door steps. The Federation encounters a number of managerial and operational problems in discharging its function. Lack of finance, excessive government control, absence of proper storage/warehouses and above all lack of any viable coordination between various nation building departments and private sector have proved a stumbling block in the successful working of the federation in Pakistan Punjab. ${ }^{21}$

In contrast, the performance of marketing societies in the Indian Punjab, considerably improved following the establishment of the State Cooperative Marketing Federation in 1967. The Markfed, undertook the task of dispensing improved seed, chemical fertilisers and pesticides to the farmers through a well developed system of village depots in the 1970s. The state 'Markfed' together with

${ }^{19}$ See Pakistan (1985) Pakistan Rural Credit Survey, pp. 514-19.

${ }^{20}$ See Pakistan (1988) Report of the National Commission on Agriculture, Chapter 23; Gill (1983), Agricultural Cooperatives-A Case Study of the Punjab, Chapters 3\&4; Kahlon (1970) Impact of Changing Conditions on Grain Marketing Institutions and the Structure of Grain Markets in Earstwhile Punjab.

${ }^{21}$ See Chaudhry (1998) Cooperatives in Punjab from 1990-91 to 1996-97, Chapter IV, pp. 30-34. 
district based organisations and the primary societies has served as a sole buying agent of food grains for the government. Randhawa points out that, at least in the trade in food grains, the Markfed has achieved considerable success by eliminating the role of middlemen and grain dealers in the Indian Punjab. ${ }^{22}$ (See Table 6).

Table 6

Working of Apex Supply and Marketing Federations in Two Punjabs

\begin{tabular}{|c|c|c|c|c|c|c|c|c|c|c|c|c|}
\hline \multirow[b]{2}{*}{ Year } & \multicolumn{2}{|c|}{ Apex Federation } & \multicolumn{2}{|c|}{$\begin{array}{l}\text { Members of the } \\
\text { Federation } \\
\text { (Number) }\end{array}$} & \multicolumn{2}{|c|}{$\begin{array}{l}\text { Working Capital } \\
\text { (Rs Million) }\end{array}$} & \multicolumn{2}{|c|}{$\begin{array}{l}\text { Value Of Produce } \\
\text { Procured } \\
\text { (Rs Million) } \\
\end{array}$} & \multicolumn{2}{|c|}{$\begin{array}{l}\text { Agri. Produce } \\
\text { Marketed } \\
\text { (Rs Million) } \\
\end{array}$} & \multicolumn{2}{|c|}{$\begin{array}{l}\text { Provision of Farm Inputs } \\
\text { (Seed, Fertiliser, } \\
\text { Pesticide) } \\
\text { (Rs Million) }\end{array}$} \\
\hline & $\begin{array}{l}\text { WP } \\
\text { (No) }\end{array}$ & $\begin{array}{c}\mathrm{EP} \\
(\mathrm{No})\end{array}$ & $\begin{array}{l}\text { WP } \\
\text { (No) }\end{array}$ & $\begin{array}{c}\text { EP } \\
\text { (No) }\end{array}$ & $\begin{array}{l}\mathrm{WP} \\
\text { (Rs) }\end{array}$ & $\begin{array}{c}\mathrm{EP} \\
\text { (Rs) }\end{array}$ & $\begin{array}{l}\text { WP } \\
\text { (Rs) }\end{array}$ & $\begin{array}{c}\text { EP } \\
\text { (Rs) }\end{array}$ & $\begin{array}{l}\text { WP } \\
\text { (Rs) }\end{array}$ & $\begin{array}{c}\text { EP } \\
\text { (Rs) }\end{array}$ & $\begin{array}{l}\text { WP } \\
\text { (Rs) }\end{array}$ & $\begin{array}{c}\text { EP } \\
\text { (Rs) }\end{array}$ \\
\hline 1970-71 & - & 1 & N.A & 118 & N.A & 747.94 & N.A & 718.88 & N.A & 543.16 & N.A & 343.28 \\
\hline $1980-81$ & - & 1 & N.A & 1527 & N.A & 2641.93 & “ & 1707.86 & “ & 2045.77 & N.A & 891.91 \\
\hline 1990-91 & 1 & 1 & 29 & 2488 & 18.08 & 9704.00 & “ & 6288.19 & “ & 6133.62 & 0.35 & 1161.14 \\
\hline 1991-92 & 1 & 1 & 29 & 2568 & 10.86 & 3355.09 & “ & 6585.78 & “ & 7607.58 & 0.75 & 1626.39 \\
\hline 1992-93 & 1 & 1 & 29 & 2685 & 23.19 & 3520.76 & “ & 6021.23 & “ & 7325.32 & 47.61 & 1807.13 \\
\hline 1993-94 & 1 & 1 & 29 & 2855 & 23.19 & 5946.56 & “ & 12282.37 & “ & 12289.31 & 127.09 & 2321.00 \\
\hline 1994-95 & 1 & 1 & 29 & 2959 & 14.54 & 10567.26 & “ & 13381.31 & “ & 9988.69 & 0.90 & 3127.62 \\
\hline
\end{tabular}

Source: 1. Statistical Abstract of Punjab (1995).

$$
\begin{aligned}
& \text { 2. Chaudhry (1998). } \\
& \text { EP: Indian Punjab. } \\
& \text { WP: Pakistan Punjab. } \\
& \text { N.A: Not applicable. }
\end{aligned}
$$

\section{RESEARCH AND DEVELOPMENT AND AGRICULTURAL SUPPORT INSTITUTIONS}

The governments in the Indian and Pakistan Punjabs launched a number of programmes to improve research and development and agricultural extension services. Special programmes for farmers were introduced through Radio and TV in both the Punjabs and as a matter of routine, the electronic media now render advice about improved farm practices and other relevant farming information. The radio was assigned a role of reporting farm prices in all the major markets in both the regions. As a part of National Community Development Programme all village Panchayats in the Indian Punjab were provided with radio sets and 99 percent of Panchayats in the villages were in their regular use. ${ }^{23}$

Although agricultural changes in both the Indian and Pakistan Punjabs have been brought about as a result of the efforts of the respective departments of Agriculture and Extension and Agricultural universities, development of agriculture

${ }^{22}$ See Sidhu and Sidhu (1991) 'Transformation of Agriculture in Indian Punjab' in Haider et al. (ed). Agricultural Strategies in the 1990s: Issues and Policies; also see Gill and Rangi (1992) 'Role of Market Infrastructure in the Development of Agriculture'.

${ }^{23}$ Sidhu and Sindhu (1991); Chaudhry and Dasgupta (1985). 
in the Indian Punjab is especially the outcome of combined efforts of and the inseparable trinity of education, research and extension. In 1957, the Punjab agricultural college was upgraded to the status of a university and was given responsibility of agricultural extension in the state. The university established a large number of experimental stations in different parts of the state, developed a close liaison with the state department of agriculture and took a lead in establishing farm advisory service for providing subject matter support to the staff of the state department and assisted them in conducting training programmes for extension personnel and the farmers. Thus when high yielding varieties of wheat and rice became available in the mid 1960s the pre-conditions for their quick adoption had already been established in the Indian Punjab. ${ }^{24}$

In contrast, after the up-gradation of agricultural college to the status of University of Agriculture, Faisalabad, the situation entirely changed in the Pakistan Punjab. The research and extension activity was taken away from the erst-while Punjab Agricultural College, Lyallpur and placed under the Departments of Agriculture and Extension with very little contact between each other and virtually

having no contact with the university. Separation of research and extension from education in the Pakistan Punjab has not only resulted in poor training of students but also deprived the university faculty and students the chance to work on practical problems of the agriculture sector and to get any feed-back from the farming community about the emerging problems in the field. ${ }^{25}$

\section{IMPACT OF RURAL INSTITUTIONS IN PLANNED AGRICULTURAL CHANGE IN TWO PUNJABS}

Let us now turn to assess the general impact of rural institutions on the development of the agricultural sector in the Indian Punjab, compared with the Pakistan Punjab. This role of rural institutions-cooperatives, credit banks and commercial banks can be studied by analysing their performance in the spread of improved farm technology (e.g. improved seed, chemical fertilisers and pesticides etc.) in the two Punjabs. The new farm technology evolved in the 1960s was generally technically appropriate to the farming conditions in the two Punjabs. Nevertheless, it is difficult to conclude that rural institutions, such as cooperatives made any significant contribution to its initial spread (see Table 7).

According to some observers ${ }^{26}$ the key constraints on the spread of improved technology did not appear to be institutional. Firstly it has been argued that the

\footnotetext{
${ }^{24}$ See Chaudhry (1979); Aulakh et al. (1998), pp. 62-82 also see Singh (1992) Development of Agricultural Research System in Punjab.

${ }^{25}$ See Ahmad and Chaudhry (1996), pp. 27-30.

${ }^{26}$ See Bhalla and Chada (1983) Green Revolution and the Small Peasant: A Study of Income Distribution among Punjab Cultivators; Chada (1986) The State and Rural Economic Transformation: A Study of Punjab 1950-85; Johl (1988) Future of Agriculture in Punjab; Ahmad and Chaudhry (1996).
} 
Table 7

Agricultural Loaned Advanced by Credit Cooperatives in Two Punjabs According to Purposes

\begin{tabular}{|c|c|c|c|c|c|c|c|c|c|c|c|c|}
\hline \multirow[b]{2}{*}{ Year } & \multicolumn{2}{|c|}{$\begin{array}{l}\text { Credit Cooperatives } \\
\text { (No) } \\
\end{array}$} & \multicolumn{2}{|c|}{$\begin{array}{l}\text { Membership } \\
\text { (No: Million) }\end{array}$} & \multicolumn{2}{|c|}{$\begin{array}{c}\text { Sort Term Loans } \\
\text { Advanced (Seed, } \\
\text { Fertiliser, Pesticides) } \\
\text { (Rs Million) } \\
\end{array}$} & \multicolumn{2}{|c|}{$\begin{array}{l}\text { Medium Term Loans } \\
\text { Advanced (Tractors, } \\
\text { Farm Implements) } \\
\text { (Rs Million) } \\
\end{array}$} & \multicolumn{2}{|c|}{$\begin{array}{l}\text { Average Loan Granted } \\
\text { Per Members (Short } \\
\text { Term Loan) } \\
\text { (Rs) }\end{array}$} & \multicolumn{2}{|c|}{$\begin{array}{l}\text { Average Loan Granted } \\
\text { Per Members (Medium } \\
\text { Term Loan) (Rs) }\end{array}$} \\
\hline & WP & EP & WP & EP & WP & EP & WP & EP & WP & EP & WP & EP \\
\hline 1978-79 & 17455 & 4271 & 0.73 & 1.75 & 145.79 & 1972.95 & 26.55 & 8.20 & 199.71 & 1127.40 & 36.37 & 4.68 \\
\hline 1980-81 & 23515 & 4266 & 0.88 & 1.78 & 958.13 & 1402.52 & 21.86 & 60.06 & 1088.78 & 787.93 & 34.84 & 33.74 \\
\hline 1990-91 & 33302 & 4633 & 1.46 & 2.04 & 2092.01 & 3456.60 & N.A & 6.49 & 1423.88 & 1694.41 & - & 3.18 \\
\hline 1991-92 & 34457 & 4570 & 1.59 & 2.06 & 2261.98 & 5216.04 & N.A & 4.25 & 1422.62 & 2532.05 & - & 2.06 \\
\hline 1992-93 & 35855 & 4485 & 1.57 & 2.08 & 2438.34 & 5379.00 & 99.13 & 217.80 & 1553.08 & 2596.05 & 63.14 & 104.71 \\
\hline 1993-94 & 33686 & 4293 & 1.57 & 2.10 & 2474.40 & 5812.11 & 20.80 & 237.28 & 1576.05 & 2767.67 & 13.24 & 112.99 \\
\hline 1994-95 & 34669 & 4205 & 1.61 & 2.06 & 2872.03 & 6440.36 & 17.55 & 204.28 & 1783.06 & 3126.38 & 10.90 & 99.16 \\
\hline
\end{tabular}

Source: 1. Statistical Abstract of Punjab (1995).

2. Chaudhry (1998).

3. Haroon (1986).

N.A Not Available. 
spread of new seeds and the concomitant increase in chemical fertiliser use were associated primarily with the availability of good irrigation systems in the two Punjabs. Secondly, as could be anticipated profitability appeared to be an important factor in the adoption of new technology in the two Punjabs (also see Table 8). However, profitability may not have been seriously influenced by rural institutions such as credit banks and cooperatives in the green revolution wheat areas in both the Punjabs. Higher market price levels, fertiliser imports and distribution policies, rural electrification and regulated markets were some of the other major factors influencing profitability, not the specific local institutions. In the Indian Punjab, price levels were indeed substantially influenced by the procurement activities of the cooperatives, undertaken on behalf of the government which virtually monopolised the wholesale grain trade within the state. The procurement prices were revised upward to a considerable extent in the face of rising production costs and increasing requirements for larger public services in both the Punjabs, but the cooperatives were only acting as government procurement agents, and only stabilised grain prices for the farmers in the Indian Punjab. This function became particularly significant in the 1970s as gluts appeared in the state market constricted by restrictions on grain export on government account. Between 1967-68 and 1980-81, for example, government procurement of wheat (on both national and state account) ranged between 30 and 73 percent of total production. In the 1960s, however, free market prices were generally higher than those received from the cooperatives in the Indian Punjab. Moreover, the government's ability to procure was less a result of the price incentives offered to farmers than of the physical restrictions on grain movement outside the Punjab.

Table 8

Net Returns of Wheat and Paddy in Two Punjab

\begin{tabular}{lccccc}
\hline \multirow{2}{*}{ Item } & \multicolumn{2}{c}{ Wheat } & & \multicolumn{2}{c}{ Rice } \\
\cline { 2 - 3 } \cline { 5 - 6 } Fixed Cost Net & 4172.46 & 6221 & & 7212.12 & 5925 \\
Operational Cost & 9456.13 & 7677 & & 7882.21 & 9998 \\
Total Cost & 13628.77 & 13898 & & 15094.33 & 15923 \\
Yield (Kg/ha) & 2150.00 & 3834 & & 1260.00 & 5255 \\
Gross Return & 8600.00 & 15758 & & 6615.00 & 19117 \\
Net Return & -5023.77 & 1860 & & -8479.33 & 3194
\end{tabular}

Source: Ahmed and Chaudhry (1996). 
The two Punjabs have been active in promoting the use of a system which linked the supply of subsidised fertiliser on credit with an approved pack of farm practices and seed. Cooperatives in both the Indian Punjab and Pakistan Punjab were employed by their respective Agriculture departments as an integral part of the general extension effort and as an instrument of government agricultural policy. The cooperative institutions were thus assigned a key role in the programme for disseminating new technology (e.g. HYV Seed, fertiliser and pesticides) in both the Punjabs (see Table 7). Thus, although rural institutions (cooperatives, credit banks etc.) played a major role in fertiliser distribution in both the Punjabs at least during the mid 1960s and in subsequent years, it was probably not the local distribution system that affected the access of farmers to inputs, but the allocation of fertiliser within the federal system of both India and Pakistan. It was this which created localised conditions of plenty and scarcity. Thus the farmers were more likely to have difficulty getting fertiliser in areas in both India and Pakistan which had low priority in national allocations than in major hybrid wheat growing areas in both the Punjabs which were assured of ample supplies.

The spread of hybrid wheat and/or chemical fertiliser use depended much more on the new technology of irrigation. The widespread access to irrigation water in the Pakistan Punjab was the result of an enhanced supply of water from an effective canal network system and improved 'On-Farm Water Management Programme' undertaken by the Department of Agriculture and the Water and Power Development Authority (WAPDA) throughout the country. In addition, heavy public investment in the installation of tubewells and subsidy granted to farmers for the installation of private tubewells were some of the other factors for enhancing supplies of irrigation water. In the Indian Punjab, on the other hand, widespread access to irrigation water was attributed to the lending activities of rural institutions, particularly the Land Development Banks. $^{27}$ Thus during the key years i.e., 1965-69, when new varieties were becoming established, public lending for tubewells represented the major share of the cost of installed wells in the Indian Punjab, and private credit for tubewells expanded only in the mid 1960s and subsequent period when lending was competitive and credit was in ample supply. This situation helped to establish new varieties by improving water control on the farm, and it also helped the smaller farmer who benefitted from an improved supply of credit at lower rates (see Table 9).

In short, the role played by the rural institutions in the spread of the use of seed of high yielding varieties and chemical fertilisers was of some significance in both the Punjabs. But the expansion of intermediate-term credit and its intimate relationship with tubewell installation for increased supplies of water was the major factor for the success of green revolution technology in the Indian Punjab.

${ }^{27}$ See Chaudhri and Dasqupta (1988) Chapter V; Aulakh (1998); Ahmad and Chaudhri (1996). 
Table 9

Number of Tubewells in Two Punjabs (In Lakhs)

\begin{tabular}{|c|c|c|c|c|c|c|c|}
\hline \multirow[b]{3}{*}{ Year } & \multicolumn{6}{|c|}{ Tubewells } & \multirow{3}{*}{$\begin{array}{c}\text { Tubewells Financed by State } \\
\text { LDBS in the Indian } \\
\text { Punjab }\end{array}$} \\
\hline & \multicolumn{3}{|c|}{ WP } & \multicolumn{3}{|c|}{$\mathrm{EP}$} & \\
\hline & Diesel & Electric & Total & Diesel & Electric & Total & \\
\hline $1970-71$ & - & - & - & 1.01 & 0.91 & 1.92 & - \\
\hline $1975-76$ & - & - & - & 3.04 & 1.46 & 4.50 & - \\
\hline 1980-81 & 1.08 & 0.68 & 1.76 & 3.20 & 2.80 & 6.00 & 2.02 \\
\hline 1985-86 & 1.50 & 0.07 & 2.23 & 2.21 & 4.41 & 6.62 & - \\
\hline 1990-91 & 2.14 & 0.82 & 2.96 & 2.00 & 6.00 & 8.00 & 2.54 \\
\hline 1991-92 & 2.29 & 0.80 & 3.09 & 1.90 & 6.22 & 8.12 & 2.57 \\
\hline $1992-93$ & 2.47 & 0.81 & 3.28 & 1.82 & 6.39 & 8.21 & 2.59 \\
\hline $1993-94$ & 3.16 & 0.80 & 3.96 & 1.81 & 6.69 & 8.50 & 2.62 \\
\hline 1994-95 & 3.36 & 0.79 & 4.15 & 1.76 & 6.84 & 8.60 & 2.67 \\
\hline
\end{tabular}

Source: 1. Statistical Abstract of Punjab (1995).

2. Facts about Punjab-1987 (1988).

3. Punjab Development Statistics (Various Issues).

EP: Indian Punjab. WP: Pakistan Punjab.

\section{CONCLUSIONS}

The rural institutions did not appear to have much impact on the early spread of high yielding varieties in the two Punjabs. This being the case, the control of rural institutions such as cooperatives by rural elites may have been less significant than the social scientists and institutional economists believe. The fact that local institutions were dominated by local élites is not the issue. What is at issue is the consequence of that domination.

The pattern of power politics in the Indian Punjab suggests that the pattern of benefits was not consistent with power politics model of institutional behaviour. The rural institutions were biased towards commercial and progressive agriculture and not towards landlords and larger farmers. Nevertheless evidence suggest that cooperatives, Agricultural Development Bank and Commercial Banks in Pakistan Punjab have been captured by landlords who may not use the benefits to further modernise agricultural pursuits and who do not want to share the benefits with less powerful neighbours. The question is why Indian Punjab is different? The obvious interpretation is that the economic context in which rural institutions operate has a major impact on the character of power relationships and decisions within the situation. In the Indian Punjab at least, a rapidly expanding rural economy brought about by the new technology and previous levels of rural investment and, the relative 
abundance of key inputs in the state, brought about by national agricultural policy, inter-class and inter-factional conflicts have produced distributive results quite different from those encountered in the Pakistan Punjab. This suggests considerable utility to the "Induced innovation" model. Market conditions in Indian Punjab and the policy context have clearly induced changes in the institutional behaviour in the state, not found in the Pakistan Punjab.

\section{REFERENCES}

Ahmad, Bashir, and M. A. Chaudhri (1996) Productivity Differential between Pakistan and Indian Punjab: An Analysis. Faisalabad: FAE \& RS, University of Agriculture.

Aulakh, K. S. et al. (1998) Vision-2020-Perspective Plan. Ludhiana: Punjab Agricultural University.

Bhalla, G. S., and G. K. Chada (1983) Green Revolution and the Small Peasant: A Study of Income Distribution among Punjab Cultivators. New Delhi: Concepts Publishing Co.

Centre for Administrative Research and Development (1984) Agricultural Cooperative Movement in Pakistan, Perspective, Problems and Plan of Action. Lahore: CARD.

Chada, G. K. (1986) The State and Rural Economic Transformation: The Case of Punjab 1950-1985. New Delhi: Sage Publications.

Chaudhri, D. P. (1979) Education, Innovations and Agricultural Development. London: Croom Helm.

Chaudhri, D. P., and Ajit K. Dasgupta (1985) Agriculture and the Development Process: A Study of Punjab. London: Croom Helm.

Chaudhry, M. E. (1998) Cooperatives in Punjab from 1990-91 to 1996-97. Lahore: Registrar Cooperatives, Government of Punjab.

Chaudhry, H. A., and A. R. Rizwani (1970) Role of Cooperative Institutions in Planned Change in West Pakistan. Faisalabad: West Pakistan Agricultural University Press.

Day, R. H., and I. Singh (1977) Economic Development as an Adoptive Process: The Green Revolution in Indian Punjab. Cambridge: Cambridge University Press.

Foster, G. M. (1962) Traditional Culture and the Impact of Technical Change. New York: Harper and Row.

Gill, K. S., and R. S. Rangi (1992) Role of Market Infrastructure in the Development of Agriculture. In J. L. Kaul (ed.) Growth of Indian Agriculture: Issues and Policies. Ludhiana: PAU Department of Economics and Sociology.

Gill, M. S. (1983) Agricultural Cooperatives-A Case Study of Punjab. Delhi: Vikas Publishing House. 
India, Government of (1974) Credit Requirements for Agriculture. New Delhi: National Council for Applied Economic Research.

Pakistan, Government of (1988) Report of the National Commission on Agriculture. Islamabad: Ministry of Food and Agriculture.

Pakistan, Government of (1985) Pakistan Rural Credit Survey. Lahore: Agricultural Census Organisation.

Punjab, Government of (1992, 1993, 1994, 1995, 1996, 1997) Punjab Development Statistics. Lahore: Bureau of Statistics.

Punjab, Government of (1980, 1982, 1983, 1986, 1990) Annual Reports of working of Cooperatives in Punjab. Lahore: Department of Cooperatives.

Punjab, Government of (1995) Statistical Abstract of Punjab. Chandigarh: Economic Adviser to Government Punjab.

Punjab, Government of (1989) Facts about Punjab-1987. Chandigarh: Govt. Press. (Report No. 28742/DPR.)

Punjab, Government of (1983). Achievement of Punjab Cooperatives at Glance Through Statistical Data. Chandigarh: Punjab Cooperative Department.

Punjab, Government of (1976) Report on the Survey of the Selected Primary Agricultural Cooperative Credit and Service Societies in Punjab. Chandigarh: Economic and Statistical Organisation. (ESO Report No. 186.)

Halpern, J. M. (1967) The Changing Village Community. New York: Prentice Hall.

Haroon, F. (1986) Cooperatives in Punjab 1979-85. Lahore: Registrar Cooperatives, Government of Punjab.

Hussain, A. (1982) Technical Change and Social Polarisation in Rural Punjab. In Karamat Ali (ed.) The Political Economy of Rural Agrarian Structure in Pakistan. Lahore: Vanguard.

Johl, S. S. (1988) Future of Agriculture in Punjab. Chandigarh: CRRID Publications.

Kahlon, A. S. (1984) Modernisation of Punjab Agriculture. New Delhi: Allied Publishers.

Kahlon, A. S., and P. L. Sankhayan (1974) Economics of Fertiliser Use in India. New Delhi: Fertiliser Association of India/FAO Seminar on Optimising Agricultural Production under Limited Availability of Fertiliser.

Kahlon, A. S. (1970) Impact of Changing Conditions on Grain Marketing Institutions and the Structure of Grain Markets in Erst-while Punjab. Ludhiana: Punjab Agricultural University Press.

Khan, M. A., D. A. Khan, and M. H. Bhatti (1973) Farm Credit Profile and Supervised Credit in Rural Pakistan. Lyallpur: University of Agriculture Press.

Khan, M. A. (1971) Cooperatives Dilemma-A study of Farm Credit Cooperatives in the Punjab. Lyallpur: WPAU Press. 
Kudaisya, G. (1995) The Demographic Upheaval of Partition: Refugees and Agricultural Re-settlement in India, 1947-67. South Asia 18: Special Issue.

Mavi, H. S. (1992) The Punjabs of India and Pakistan. The Tribune, 28 May. Chandigarh: Punjab.

Mustafa, K. (1992) The Institution of Cooperation, Credit and the process of Development in the Indian and Pakistan Punjabs. Unpublished Ph.D. Thesis, Glasgow: Department of Political Economy.

Myrdal, G. (1968) Asian Drama: An Inquiry into Poverty of Nations. 3 Vols. London: Allen Lane Penguin Press.

Randhawa, M. S. (1974) Green Revolution: A Case Study of Punjab. New Delhi: Vikas Publishers.

Randhawa, M. S. (1954) Out of Ashes, An Account of the Rehabilitation of Refugees from West Pakistan to the Rural Areas of East Punjab. Chandigarh: Public Relations Department.

Reserve Bank of India (1981) Report of the Committee to Review Arrangements for Institutional Credit for Agriculture and Rural Development-CRAFICARD Bombay: RBI.

Sidhu, D. S., and J. S. Sidhu (1991) Transformation of Agriculture in Indian Punjab. In A. S. Haider et al. (ed.) Agricultural Strategies in the 1990s: Issues and Policies. Islamabad: Pakistan Association of Agricultural Social Scientists.

Sims, Holly (1988) Political Regimes, Public Policy and Economic Development: Agricultural Performance and Rural Change in the Two Punjabs. New Delhi: Sage Publications.

Singh, Avtar (1999) Punjab Agricultural Handbook. Ludhiana: Punjab Agricultural University.

Singh, K. (1992) Development of Agricultural Research System in Punjab, Indian. Journal of Agricultural Economics 4:3.

Singh, G. (1972) A Study to Assess the Effects of Green Revolution upon the Social Structure of Rural Society under IADP in Ludhiana District. Ludhiana: Information Unit of IADP.

Singh, Rajinder, and A. S. Roupra (1982) Achievements of Punjab Cooperatives at a Glance through Statistical Data from 1967 to 1981. Chandigarh: Punjab Cooperative Union. 


\section{Comments}

I must say at the outset that I am happy to offer my comments on the paper not that I have officially been assigned that task but because it is a well-written paper and the authors deserve full appreciation, encouragement and congratulations for putting up solid empirical and theoretical evidence in favour of derived conclusions. I must confess that I gained considerable insight into the subject after reading the paper. Some of the salient features of the paper that lead to higher productivity (almost double) of agriculture in the Indian (East) Punjab relative to Pakistani (West) Punjab, can be recounted as follows:

Firstly, although both the Punjabs shared the same tenurial system and land distribution prior to 1947, radical land reforms in East Punjab after partition successfully created a society of small farmers which propagated a culture of selfcultivating peasant proprietors. In West Punjab on the other hand, land reform attempts had only limited success and large land holdings employing tenants and landless labourers for cultivation remained a dominant feature of agriculture. As owner-operated small farms tend to be more productive than the large tenant-and/or landless labour-operated farms, it remains a factor in the high productivity of Indian Punjab.

Secondly, the paper convincingly argued that Indian Punjab's higher productivity is attributable to rapid and more comprehensive financial development for disbursement of credit to agricultural sector particularly to small farmers through cooperative societies and Banking Institutions. By contrast both Banks and Cooperative societies in Pakistan served mainly the large farmer's interests and failed to meet the credit needs of resource-poor small farmers.

Thirdly, the Indian government seemed to be more alive to issues in agricultural development and followed a more consistent agricultural policy. For example, the agriculture and water sectors continued to receive dominant share of public sector allocation in India against progressively falling and insignificant shares in Pakistan with passage of time. The Indian government has followed a carefully devised policy of price incentives for agriculture and has provided huge subsidies on tubewell installations and operation, fertilisers, pesticides and seeds. This compares with Pakistan's situation where agriculture receives little support from the government. The Public allocations to agriculture have drastically declined in the recent years relative to the 1960s. The price incentives have been weak and profit rates have been declining since the 1980s under sharply rising prices of key agricultural inputs as a result of government commitment to withdraw all subsidies from agriculture and uncertain and lower than world commodity prices which can crumble as market gluts appear in response to even slight surpluses over and above domestic demand. 
Fourthly, there have been important differences in the marketing system of the two Punjabs. East Punjab had a more or less competitive marketing system against open ended monopolistic system in West Punjab. Indian Punjab had been typically characterised by the privately operated system of regulated markets which ensures fair prices for agriculture. The system is made more competitive as the government undertakes procurement operations alongside the private marketing system. In Pakistani Punjab regulated market system was dismantled in the early 1970s, and had been in disarray since then. In the absence of regulated markets, Pakistan's agricultural marketing system has conspicuously been marked by monopolies of government, industrialists and village Beoparis working in collusion with each other. In addition, the Indian Punjab was well-versed with market infrastructure and farm to market roads which passed through each and every village but the road infrastructure was, at best, sparce in Pakistani Punjab.

Finally, the research, teaching and extension had viable and active links between them and with the farmers and made concerted efforts to educate the farmers in a precise manner about the new technology in the Indian Punjab. In West Punjab, there were only weak links between these three departments. In fact each of them operated independently under separate administrative units. Although extension service made some positive contributions to output by promoting rapid spread of technology in the Sixties, its interaction with farmers has faded into insignificance with passage of time especially since the introduction of $\mathrm{T}$ and $\mathrm{V}$ programme. Needless to add that teaching or research staff in Pakistan has never had a formal direct link with the farmers.

Despite my general agreement with the paper's conclusions, the importance of above factors in the rapid growth of agricultural productivity in Indian Punjab is perhaps over emphasised for at least three reasons. Firstly, those familiar with the region would largely agree that the Indian Punjab had a more conducive natural resource endowment than Pakistani Punjab for the production of most agricultural commodities. West Punjab is far more arid than East Punjab. In a normal year, rainfall would usually exceed 40 inches anywhere in East Punjab against the average annual precipitation of 8 inches in West Punjab. Thus the high rainfall does not only permit successful crop cultivation even without irrigation, it also allows rapid recharge of the underground water aquifer in East Punjab which can be pumped by tubewells as needed. In addition, the proximity to high mountains and higher elevation of East Punjab than the West, ensures a colder and somewhat prolonged winter season which is highly conducive for maximising wheat yields.

Secondly, being canal-irrigated for more than 100 years, West Punjab inherited waterlogging and salinity from pre-independence period whereas the problem did not exist in East Punjab. Further, East Punjab has well-drained soils and adequate natural drainage due to its deep slope and topography but West Punjab’s flat plateau has to be provided with artificial drainage. Almost all of East Punjab is underlain with fresh underground water aquifer but sub-soil water in major areas of West Punjab is brackish 
and unfit for irrigation. As must be clear, these factors could have only adverse effect on crop yields in West Punjab.

Finally, the comparisons of individual crop yields may sometimes be misleading because of variations in cropping patterns and even varieties of crops grown. The cropping pattern followed in the Indian Punjab heavily concentrates on wheat and rice (coarse) but in the West Punjab mixed cropping is the main pattern. For a harmonious treatment of the two regions, aggregate productivity should be the basis of comparisons. Lacking such comparisons, the study's limitations must be obvious especially in terms of cautious interpretation of its conclusions. Also, it seems to be vague to compare rice yields because the two Punjabs grow different varieties of rice. In the Indian Punjab IRRI (coarse) rice has mainly replaced Basmati (superior) rice cultivation. But Pakistani Punjab continues to specialise in Basmati rice cultivation. As the yield of coarse rice varieties is always higher than that of Basmati, higher rice productivity of East Punjab should be quite understandable. The cultivation of coarse rice would also have a more favourable impact on wheat yields in Indian Punjab because early maturity of IRRI rice would permit timely sowing of wheat crop.

In the end let me once again conclude that the paper under review has considerable merit and must be appreciated for its valid analytical and solid empirical contents.

Pakistan Institute of Development Economics,

M. Ghaffar Chaudhry

Islamabad. 